Journal of Economic Theory 6(1): 37-41, 2012

ISSN: 1994-8212

(C) Medwell Journals, 2012

\title{
The Introduction of Conditional Hibah as Islamic Financial Instruments
}

\author{
Abdel Wadoud Moustafa Moursi El-Seoudi, Muhammad Nazir Alias, Mohd. Nasran Mohamad, \\ Amir Husin Mohd. Nor, Zaini Nasohah and Nik Abdul Rahim Nik Abdul Ghani \\ Department of Syariah, Faculty of Islamic Studies, Universiti Kebangsaan Malaysia, \\ 43600 Bangi, Selangor, Malaysia
}

\begin{abstract}
Islamic banking system is a system that emphasizes justice and avoid injustice to buden the riba of the loan. Anumber of financing instruments have been introduced by Muslim scholars in order to achieve these objectives. Between existing instruments such as sale al'Inah and Tawarruq. However, both of these instruments still have seen elements of usury by some experts in Islamic finance. This study aims to explain the conditional grant in accordance with the law and explain the relevance of past jurists to be one of the Islamic financing instruments. The study will examine the books containing the views of jurists from different schools to get a clear picture of this problem and then find the best and moderate views. Based on this view, this study explains how the grant agreement can become an instrument of financing in the Islamic financial system.
\end{abstract}

Key words: Hibah, Islam, conditional, Islamic financial instruments, Islamic banking system, Malaysia

\section{INTRODUCTION}

Islamic banking known as an ideal and fair economic system because of the continuing effort in prohibiting riba (usury) in all kind of activities. Usury is forbidden by Syariah Islamiyyah (Islamic Law) because of the oppression concept on borrowers who need it. Since decades, Islamic financial instruments used numbers of contracts such as al-Tawaruq and al'Inah yet still in dispute among Islamic researchers as they considered those contracts still involves elements of usury. Based on that this research will do an explanation of Hibah System as an alternative system to replace the al-Tawarruq and al'Inah system. The explanation focused more on the discussion of jurisprudence angle than the banking practices.

\section{DEFINITION OF Al'INAH (SALE ON CREADIT)}

There are several different meanings of al'Inah but the most sense given refers to the purpose of selling goods with creadit and buy back price in cash from buyer at a price lower than the selling price (Al-Zuhayli, 2009). For example, a customer will seek a bank and buy assets from the bank at high price with creadit and resell it to the bank with a lower price in cash.

Principle of al'Inah: According to Al-Syafie Muhammad Ibn Idris (1983), al'Inah is mubah (permitted contract). According to the Hanafi scholars, al'Inah has many forms and one of them as stated by Imam al-Shafie. Although, Abu Yusuf viewed that it is allowable but according to Abu al-Su'ud, it means that if the goods are sold to third party. Therefore, the Hanafi scholars viewed that the al'Inah is makruh tahrimi (abominable to the degree of prohibition) (Ibn Abidin Muhammad Amin, 1995).

Meanwhile, according to Maliki researchers (Khalil Ibn Ishaq al-Jundi, 1995) and Hanbali (Ibn Qudamah Abdullah Ibn Ahmad, 1999), al'Inah is illegal as it is a ploy to allow usury because the goods are included in the contract to allows debt given in cash and paid by delay payment with increase price. According to Ibn Qudamah Abdullah Ibn Ahmad (1999), it is the view narrated from Ibn'Abbas, Saidatina Aishah, Imam Al-Hasan, Ibn Sirin, Al-Sya'bi, Al-Nakhaci, Al-Thauri, Al-Awzai, Imam Malik and Imam Ishaq. This view was also accepted by most scholars of the Middle East today (Shamsiah, 2007). Therefore, al'Inah not practice in the Islamic banking in the Middle East because it is still involve with usury.

\section{DEFINITION OF AL-TAWARRUQ}

Al-Tawarruq means to purchase goods with credit and reselling it to another third party for cash at a price lower than the purchase price for cash (Al-Zuhayli, 2009; Al-Salus, 2005).

Principle of al-tawarruq: The majority of Islamic scholars permitted al-Tawarruq because those parties in the contract not intent to commit in usury (Al-Zuhayli,

Corresponding Author: Abdel Wadoud Moustafa Moursi El-Seoudi, Department of Syariah, Faculty of Islamic Studies, Universiti Kebangsaan Malaysia, 43600 Bangi, Selangor, Malaysia 


\section{J. Econ. Theroy, 6 (1): 37-41, 2012}

2009). Umar ibn Abd al-Aziz and Muhammad ibn Hasan al-Syaibani viewed that al-Tawarruq is makruh (reprehensible) while Ibn Taymiyyah and Ibn al-Qayyim viewed it is illegal because it is regarded as sale without intention.

In conference of the 15 th Majma $^{c}$ al-Fiqh al-Islami, al-Tawarruq has been accepted as mubah (permitted) (Al-Zuhayli, 2009). In resolution $179 \mathrm{Majma}^{\mathrm{c}}$ al-Fiqh al-Islami al-Duwali, al-Tawarruq was accepted as a valid sale and free from riba. However, al-Tawarruq is widely practiced in Islamic banking has been banned by Majma ${ }^{\circ}$ al-Fiqh al-Islami al-Duwali because it was seen contain many collusion between the bank and the customer is considered as a ploy to allow usury. Al-Tawarruq is defined as a customer purchase of local or international goods with credit and then the bank as representative to their customers or through the bank's representative directly sell the product with a lower cash price. The al-Tawarruq is known as al-Tawarruq al-Munazzam. Al-Tawarruq al-Munazzam is illegal because the consent of the customer to the bank represented to sell items that have been purchased from the bank itself cause it seems like al'Inah since the sale takes place between the both parties only. It also denied al-Qabd (give and recieve) conditions stipulated in contract between the customer and third party in the transaction of business represented by the bank.

Al-Tawarruq al-Munazzam is practiced in order to facilitate customers so that they are not burden with the purchased goods from the bank to the third party. The fatwa seemed to ban all financial activities that are practiced by the Islamic banks at present.

\section{DEFINITION OF HIBAH}

Hibah means the ownership of property without any exchange, purchase or sale. If ownership is intended solely for the consideration hereafter, it is called charity. If the property is taken to the intended recipient as to respect either for consideration or not, it is called a gift. If it is not intended to reward hereafter and it is not taken to a recipient, it is called grant.

Legality of hibah: Hibah is mubah (permitted) in Islam based on the Qur'an: And give the women their dowries willingly. But if they, of their own pleasure of heart remit something of it to you then consume it with taste and pleasure. Word of the Prophet Muhammad (PBUH): Giving gifts will bring love to each other (Al-Bayhaqi Ahmad Ibn al-Husayn, 1994).

Principle of hibah: Original law of hibah is the recipient assigned to the goods without any reward. According to the Hanafi scholars, hibah contracts is allowed contract so that the contract can be taken back as long as there is no retward from recipient.

According to the Maliki scholars, the contract has become fixed if the recipient has received the item and can not be returned except hibah from a father to his children with certain conditions. While the hibah was intended for the sole reward, it can not be taken back once given even via buy-back (Ibn Rusyd Muhammad Ibn Ahmad al-Qurtubi, 1995). According to Syafie scholars and Hambal scholars, it is illegal for the giver to take back the gift unless the gift from a father to his children. Included also in terms of the father is the progenitor and upward (Al-Syafie, Muhammad Ibn Idris, 1983; Ibn Qudama Abdullah Ibn Ahmed, 1999).

In conclusion, the Hibah is a allowed contract to the Hanafi scholars and it is fixed contract according to the bunch consensus Islamic scholars unless the gift from a father to his children which the father is allowable to cancel his intention about giving the gift or after pursuant to sect of Shafie scholars and sect of Hanbali.

\section{CONDITIONAL HIBAH}

According to most scholars of Hanafi, Hanbali and Shafie in a acceptable view, the original of the hibah contract is tabarru ${ }^{c}$. Tabarru ${ }^{c}$ is the recipients do not need to give something in return for the hibah (Ibn Qudamah Abdullah Ibn Ahmad, 1999). According to the Maliki researchers (Ibn Rusyd Muhammad Ibn Ahmad al-Qurtubi, 1995) contract of hibah is also intended to reward, especially if there is relevant to show such as gift the poor to the rich in order to get a better response. According to al-Sarakhsi, the reward between the hibah contract itself and hibah in the sale contract are different which the reward in the contract of sale is required while the reward in the hibah contract is intended and not requirement. This is based on the hadith which a reason to create love and affection between the parties mutually provide gifts. According to the Shafie scholars in the Al-azhar view should be given consideration for reward if the hibah is from the poor to the rich. However, if the conditional hibah required in the contract, how is the principle of the condition in Islamic view?

According to the consensus scholars from Hanafi, Maliki, Hanbali and Shafie's al-azhar view, the conditional is valid (Al-Kasani, Abu Bakr Ibn Su'ud, 2000; Al-Syarbini Muhammad Ibn al-Khatib, 1997; Ibn Qudamah Abdullah Ibn Ahmad, 1999; Ibn Rusyd Muhammad Ibn Ahmad al-Qurtubi, 1995). Their sources is based on the word of the Prophet Muhammad (PBUH): The giver has more rights to his gift (Hibah) as long as he not given anything (Al-Bayhaqi Ahmad Ibn al-Husayn, 1344). 


\section{J. Econ. Theroy, 6 (1): 37-41, 2012}

According to the Shafie sholars as well as al-azhar view and a view from Hanbali scholars, the condition is invalid because it was against the hibah itself by giving without any return (Al-Syarbini Muhammad Ibn al-Khatib, 1997; Ibn Qudamah Abdullah Ibn Ahmad, 1999).

According to the consensus of Islamic scholars, the return must be clearly defined as in the sale and purchase contract. If the required of the conditional return is not clear, according to the Hanbali scholars, the hibah contract is fasid (deteriorate) like sale and purchase contract. The goods must be returned. If the goods are damaged, hibah recipients should return the price. The discussion is to them the hibah is the sale and purchase contract and require the consent of both parties (Ibn Qudamah Abdullah Ibn Ahmad, 1999).

According to the Shafie scholars, hibah that not express clearly about the reward is batil (null) because it cannot be a sale and purchase contract and cannot be a hibah contract because the hibah contract is not intended to be returned (Al-Syarbini Muhammad Ibn al-Khatib, 1997). According to a another view, the contract also contains an intention to get reward. Thus, if reward is not explained, it is a valid Hibah. According to Al-Nawawi, this is the view held by the majority Islamic sect and Shafie scholars. According to Imam Ahmad which imposes a condition of reward is not clear, the hibah contract is valid and if the hibah recipient give something for return and acceptable by the provider, the contract will be lazim (fixed contract) (Ibn Qudamah Abdullah Ibn Ahmad, 1999). According to the Hanafi scholars, the hibah with conditional is valid. It took the hibah principle before the al-qabd (give and receive) contract and take the sale and purchase principle after al-qabd (give and receive). Therefore, it becomes a hibah contract before and a sale and purchase contract afterwards. While if the hibah reward is not clear from beginning, the conditions to be null and it became the hibah contract at the beginning and the end because the hibah does not invalidate by the defective of the condition (Al-Kasani, Abu Bakr Ibn Su'ud, 2000). Meanwhile, according to Maliki researchers (Ibn Rusyd Muhammad Ibn Ahmad al-Qurtubi, 1995) if the hibah required the reward is not specified and the contract has not been granted, the hibah does not become endemic to the giver. But if the grant was given to the recipient, it became lazim (fixed contract) to the provider and not endemic to the recipient, he may return it or return the price if there is an increase or lack of value (Al-Khurasyi, 1975).

Principle of conditional hibah: Based on the above discussion, scholars dispute the view of the principles which imposes the condition in hibah contract in several views: Maliki scholars view, Shafie scholars authentic point of view according to the sect and the Hanbali scholars according to the Zufar view of the Hanafi sect which imposes a condition in Hibah contract is a sale and purchase contract at the beginning and the end (Al-Syarbini Muhammad Ibn al-Khatib, 1997; Ibn Qudamah Abdullah Ibn Ahmad, 1999; Ibn Rusyd Muhammad Ibn Ahmad al-Qurtubi, 1995). Therefore, it is not cancel contract if any part of the shuyu ${ }^{c}$ (partnership) is not determined and ownership after the contract without having qabd (give and receive). Providers and hibah recipients can not revoke the contract. According to Zufar, his view is the purpose of trading in a contract exists is because it is a possession of the goods for a reward but using another pronounce from the sale and purchase contract. The difference does not affect the pronouncement of the principle because there had been trading with the pronouncement of ownership (Al-Kasani, Abu Bakr Ibn Su'ud, 2000).

According to Imam Abu Hanifah, Abu Yusuf, Muhammad ibn al-Hasan and a view of Imam Shafie and Imam Ahmad, conditional Hibal is hibah contract from the beginning and the end of contract if happened qabd (get and receive) by both parties (Al-Kasani, Abu Bakr Ibn Su'ud, 2000). Hanafi scholars say: Before qabd (give and receive) happen by both parties does not occur ownership and any party may cancel the hibah despite qabd (give and receive) happened on one side only. If qabd has occurred on both sides, it becomes a sale and purchase contract and each of them may return the goods if there any damage.

According to Ibn Nujaym Zaynuddin Ibn Ibrahim (1997) if a person is forced to do conditional hibah, it becomes a sale and purchase contract at the beginning and end. Their statement is that has existed in this contract the meaning of the pronouncement of hibah and sale and purchase transactions. Therefore, it is necessary to take both the principles as far as possible. The need to qabd (give and receive) to be hibah contract and may be returned if there is damage as in the sale and purchase contract (Al-Kasani, Abu Bakr Ibn Su'ud, 2000). Abu al-Khattab took Imam Ahmad's view that which imposes a condition more serious consideration to the principle of hibah contract and does not take place of sale and purchase contract (Ibn Qudamah Abdullah Ibn Ahmad, 1999). Al-Harithi has supported this view and Al-Qadhi has explained it he said: Conditional hibah is not a sale and purchase contract as consideration for reward may be occurring on a voluntary basis and may occur with a reward such as freeing slaves (Al-Mardawi Ali Ibn Sulaiman, 1955). 


\section{STATUS OF UNCONDITIONAL HIBAH WITH REWARD}

Hanafi, Shafie and Hanbali scholars in accordance with the view that consideration of reward absolutely Hibah is basically another hibah (Al-Kasani, Abu Bakr Ibn Su'ud, 2000; Ibn Qudamah Abdullah Ibn Ahmad, 1999). According to the Hanafi scholars: they take the principle of hibah contract from the angle of the sah (valid) and batal (invalid) except for the first hibah canceled by the existence of the second hibah (Al-Kasani, Abu Bakr Ibn Su'ud, 2000).

According to Mutawalli from Shafie sect., if the grant is not required a reward but the recipient reply in the contract included in the hibah between a father to his child if any reward from a child to the father not drop the father's right to cancel the hibah.

\section{HIBAH BASED ON DEBT FINANCING}

Hibas based on debt financing is different from al'Inah and al-Tawarruq because both these contracts is based on only one item between the bank and the customer. That is the selling of goods by the bank to the customer on the delayed payment and sales back to the bank or third party for cash. Based on the conditional hibah, there are two things involved in debt financing of hibah and contract of sale and purchase. In the financing, the customer will hibah a goods to the bank. After qabd (give and receive) happens, customers will buy back the goods at the cost of respite.

While, the bank will hibah a possession of goods to customers and after a qabd (give and receive), the bank will buy back the goods for cash. In this way, the purpose of financing required can be achieved. Figure 1 shows how the hibah based on transactions occurred in private financing.

In the above first purchase transactions, the customer will hibah a car to the bank and buy the hibah back with RM50,000. After that the bank hibah a customer a piece of gold bars and buy back the price of RM40,000. In this case, the bank and the customer doing hibah without being required a reward in the contract.

Based on the views of researchers on the transaction is permitted because there are two different transactions on the two items that differ between the bank and customers. It is a grant that awarded hibah without condition and expressed in the contract.

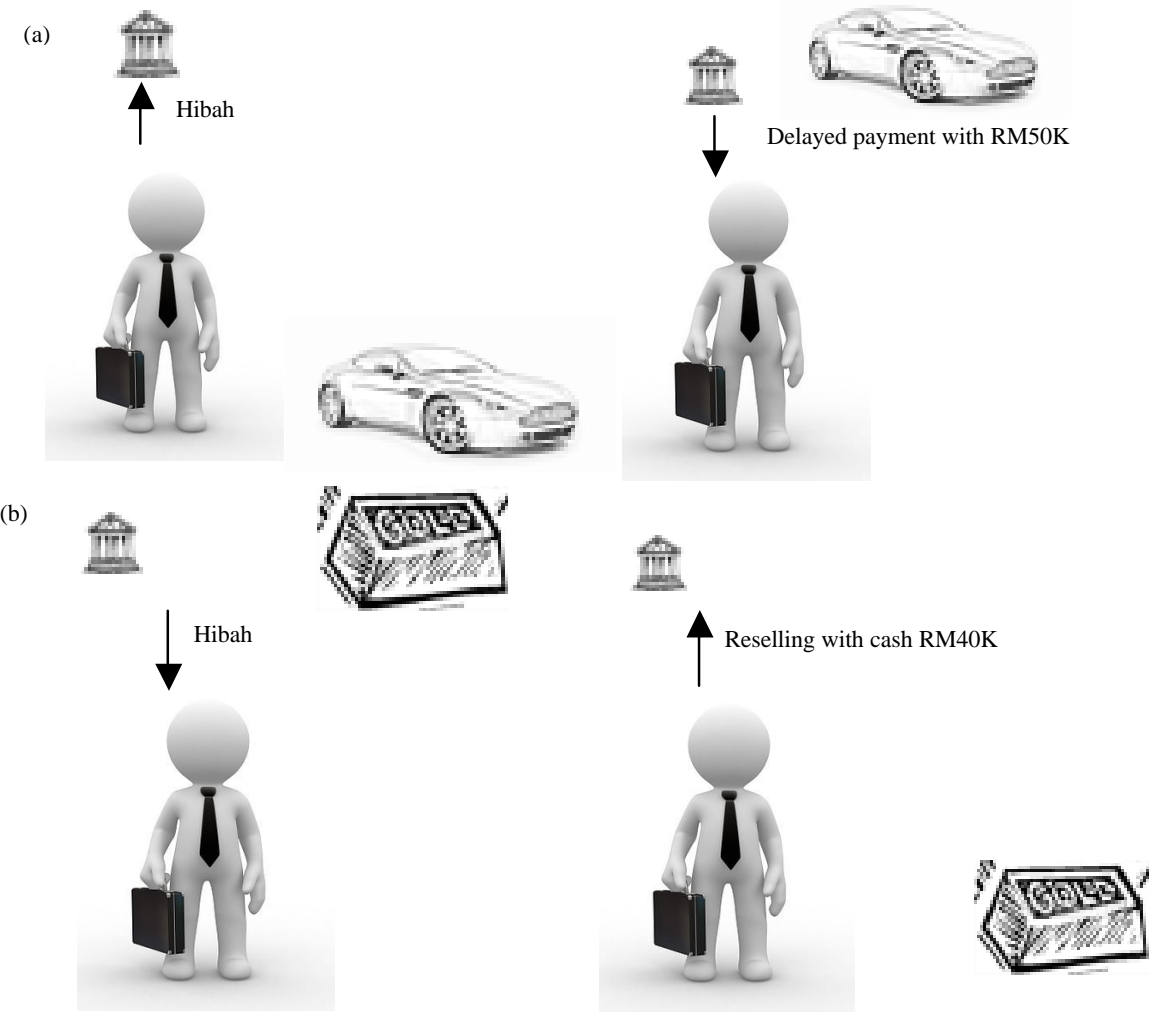

Fig. 1: The hibah based on transactions occurred in private financing; a) First purchase; b) Second purchase 


\section{CONCLUSION}

In the study, the hibah based on the debt financing can be an alternative to overcome the concerns raised on debt financing based on al'Inah and al-Tawarruq. Hibas based on debt financing is different from alcInah and al-Tawarruq because both these contracts is based on only one item between the bank and the customer. That is the selling of goods by the bank to the customer on the delayed payment and sales back to the bank or third party for cash.

Based on the conditional hibah, there are two things involved in debt financing of hibah and contract of sale and purchase. In the financing, the customer will hibah a goods to the bank. After qabd (give and receive) happens, customers will buy back the goods at the cost of respite. While the bank will hibah a possession of goods to customers and after a qabd (give and receive), the bank will buy back the goods for cash. In this way, the purpose of financing required can be achieved.

\section{ACKNOWLEDGEMENT}

Part of this stady is an outcome of research was conducted by using the research funding of the UKM-PP-05-FRGS0170-2010 Project.

\section{REFERENCES}

Al-Bayhaqi Ahmad Ibn al-Husayn, 1994. al-Sunan alKubra. Mekah: Maktabah Dar al-Baz.

Al-Bayhaqi Ahmad Ibn al-Husayn, 1344. al-Sunan alKubra. Hyderabad: Majlis Da'erah al-Ma'arif alNizamiyyah.
Al-Kasani Abu Bakr Ibn Su'ud, 2000. Bada'i al-Sana'i Fi Tartib al-Syara'i. Beirut: Dar Ihya' al-Turath al-'Arabi. Al-Khurasyi, M., 1975. Al-Khurasyi 'Ala Mukhtasar Sidi Khalil. Beirut: Dar al-Sadir.

Al-Mardawi Ali Ibn Sulaiman, 1955. Al-Insaf Fi Ma'rifah al-Rajih Min al-Khilaf 'Ala Madhhab al-Imam Ahmad Ibn Hanbal. Qaherah: Maktabah al-Sunnah alMuhammadiyyah.

Al-Salus, A.A., 2005. Al-Tamwil Bi al-Tawarruq. Mesir: Maktabah Dar al-Qur'an.

Al-Syafie MuhammadIbn Idris, 1983. Al-Umm. Beirut: $r$ alFikr. Cetakan Kedua.

Al-Syarbini Muhammad Ibn al-Khatib, 1997. Mughni alMuhtaj Ila Ma'rifah Ma'ani Alfaz al-Minhaj. Beirut: Dar al-Ma'rifah.

Al-Zuhayli, W.M., 2009. Al-Tawarruq: Haqiqatuh Wa Anwa'uh. Imarat: Majma' al-Figh al-Islami. Kertas Persidangan.

Ibn Abidin Muhammad Amin, 1995. Hasyiyah Radd alMuhtar 'Ala al-Dur al-Mukhtar. Beirut: Dar al-Fikr.

Ibn Nujaym Zaynuddin Ibn Ibrahim, 1997. Al-Bahr alRa'iq Syarh Kanz al-Daqa'iq Fi Furu' al-Hanafiyyah. Beirut: Dar al-Kutub.

Ibn Qudamah Abdullah Ibn Ahmad, 1999. al-Mughni. AlRiyad: Dar 'Alam al-Kutub.

Ibn Rusyd Muhammad Ibn Ahmad al-Qurtubi, 1995. Bidayah al-Mujtahid Wa Nihayah al-Muqtasid. Beirut: Dar al-Fikr.

Khalil Ibn Ishaq al-Jundi, 1995. Mukhtasar Khalil. Beirut: Dar al-Kutub al-'Tlmiyyah.

Shamsiah, M., 2007. Isu-Isu Dalam Penggunaan Bai' al'Inah and Tawarruq: Perspektif Hukum dalam Bai' al'Inah Dan Tawarruq: Isu-Isu Dan Penyelesaiannya Dalam Konteks Kewangan Islam. Kuala Lumpur: Bank Negara Malaysia. 